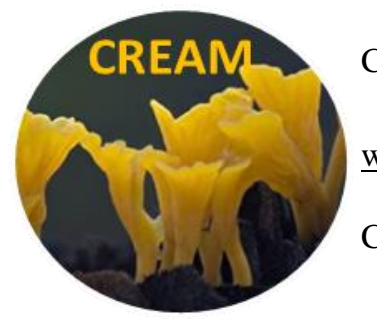

\title{
Detection and quantification of trace elements (Chromium, Vanadium, Selenium) in some Ghanaian mushrooms using atomic absorption spectrometry
}

\author{
Quarcoo $\mathrm{A}^{\mathbf{1}}$, Adotey $\mathrm{G}^{\mathbf{1}}$ and Gordon $\mathrm{A}^{\mathbf{1}}$ \\ ${ }^{1}$ Accra Polytechnic, Science Laboratory Technology Department, Box GP 561, Accra.
}

Quarcoo A, Adotey G, Gordon A 2014 - Detection and quantification of trace elements (Chromium, Vanadium, Selenium) in some Ghanaian mushrooms using atomic absorption spectrometry. Current Research in Environmental \& Applied Mycology 4 (1): 142-148, Doi $10.5943 / \mathrm{cream} / 4 / 1 / 13$

\begin{abstract}
Trace metallic elements such as Chromium (Cr), Vanadium (V), and Selenium (Se) have potential beneficial effects on glucose metabolism in people with non-communicable diseases especially type 2 diabetes. This study was conducted to determine the presence and concentration of trace elements (Chromium, Vanadium, and Selenium) in the fruiting bodies of fresh mushrooms commonly consumed in Ghana namely, Pleurotus ostreatus (oyster mushroom), Agaricus bisporus (button mushroom), Ganoderma lucidum (wild Ganoderma), Termitomyces clypeatus (common edible mushroom). Ganoderma lucidum was obtained from the wild while the others came from the market. The concentration of these metals $\mathrm{Cr}, \mathrm{V}$, and $\mathrm{Se}$, as determined by Atomic Absorption Spectrophotometry (AAS) was found to be $0.6 \mathrm{mg} / \mathrm{kg}, 0.4 \mathrm{mg} / \mathrm{kg}$, and $334.48 \mathrm{mg} / \mathrm{kg}$ respectively in button mushroom, $1.3 \mathrm{mg} / \mathrm{kg}, 0.4 \mathrm{mg} / \mathrm{kg}$, and $375.78 \mathrm{mg} / \mathrm{kg}$ respectively in common edible mushroom, $0.2 \mathrm{mg} / \mathrm{kg}, 0.4 \mathrm{mg} / \mathrm{kg}$, and $466.12 \mathrm{mg} / \mathrm{kg}$ respectively in oyster mushroom, and $0.96 \mathrm{mg} / \mathrm{kg}, 0.4 \mathrm{mg} / \mathrm{kg}$, and $420.06 \mathrm{mg} / \mathrm{kg}$ respectively in Ganoderma lucidum. The highest concentrations of these metals were $\mathrm{Cr}(1.3 \mathrm{mg} / \mathrm{kg})$ found in Termitomyces clypeatus; V (0.4 $\mathrm{mg} / \mathrm{kg}$ ) for all of them; and Se $(466.12 \mathrm{mg} / \mathrm{kg})$ in Pleorotus ostreatus. The mushrooms here examined may be considered as safe sources of trace minerals reputed to be of some value in the metabolism of glucose and hence beneficial in controlling the incidence and management of type 2 diabetes and its effects.
\end{abstract}

Key words - Agaricus bisporus - atomic absorption spectroscopy - chromium - Ganoderma lucidum - mushrooms - Pleurotus ostreatus - selenium - Termitomyces clypeatus - vanadium

\section{Introduction}

Although mushroom consumption in Ghana may be said to be on the rise in terms of the total amount consumed, the variety of mushrooms consumed is heavily biased towards Pleorotus ostreatus. This is because the oyster mushroom is easily cultivated by many small scale producers and effectively marketed fresh or dried. It is mostly available in urban areas where these small scale farms are located. Comparatively, Termitomyces clypeatus (edible mushroom) is collected from the wild by artisanal collectors in the rural and peri-urban areas who bring them to the urban markets in the capital Accra. Consumption of Termitomyces is therefore found both in urban and rural areas 
and is preferred because of its taste. Agaricus bisporus is not locally produced, but is usually available either fresh or dried at supermarkets in urban centres as imports from other countries like South Africa. Ganoderma lucidum is mainly known for its medicinal properties and harvested by herbalists who use it in various medicinal potions.

In the treatment of non-communicable diseases like type 2 diabetes, allopathic medicine relies heavily on the use of chemically derived medicines to manage or treat these ailments. There is in general a move away from the sole use of chemically derived medicines for diabetes to a new paradigm in which chemically derived medicines are combined with natural products of proven ability to reduce hyperglycaemia. In some cases, there is a total dependence on these natural products for diabetic management. For such natural products to be effective, they must possess ingredients that helps modulate and control or improve these conditions. For the mushrooms in question here, various reasons have been proffered as to why they have proven beneficial especially in the management of type 2 diabetes. Agaricus bisporus (Sang Chul Jeong et al. 2010), Termitomyces clypeatus(Yang B.K. et al. 2002) Ganoderma lucidum (Zhang \& Lin 2004), and Pleorotus ostreatus (Inas S. et al. 2011) have all been demonstrated to have antihyperglycemic properties.

Dobrinas S. et al. (2013) determined levels of trace elements in three fresh mushroom species includinig Agaricus bisporus and Pleurotus ostreatus using UV/Visible spectrophotometry. Chromium was detected to be present within the range of $0.01-2.26 \mathrm{mg} / \mathrm{kg}$. In their work, they detected that Pleurotus cuticle had the highest concentration of chromium while white Romanian button mushroom stems contained the lowest values. In a comprehensive review, Kalac (2010) noted chromium levels in numerous species to range between $0.5-5 \mathrm{mg} / \mathrm{kg}$ dry matter and less frequently between $5-10 \mathrm{mg} / \mathrm{kg}$ dry matter (Demirbas, A. 2001; Isildak Ö. et al. 2004). Kalac (2010) also noted that chromium concentrations above $10 \mathrm{mg} / \mathrm{kg}$ dry matter were reported in several species. Konuk M (2007) determined that the heaviest amount of chromium in mushrooms from the western Black Sea Region of western Turkey were found in Sarcodon leucopus (1 $\mu \mathrm{g} / \mathrm{g}$ dry weight) and Morchella costata ( $1.68 \mu \mathrm{g} / \mathrm{g}$ dry weight).

Chromium is generally recognized to play an important role in glucose and lipid metabolism. Chromium appears to be involved in carbohydrate, protein, and fat metabolism and it may enhance blood sugar control in individuals with diabetes. One effect of chromium is that it is very helpful in preventing and reversing type 2 diabetes because plasma glucose is more effectively regulated in the presence of chromium (Anderson RA et al. 1997).

$\mathrm{Cr}$ and its biologically active form the glucose-tolerance factor (GTF) have been implicated in the pathogenesis of certain forms of glucose intolerance and diabetes mellitus (Schroeder HA 1966, Jeejeeboy KN et al.1977 \& Freund H et al. 1979). Experiments in rats (Schroeder HA 1966, Wolliscroft \& Barbosa 1977) and squirrel monkeys (Davidson IWF 1968) demonstrated that dietary deficiency of $\mathrm{Cr}$ can result in elevated blood glucose, triglycerides, and cholesterol levels. Administration of $\mathrm{Cr}$ readily reversed these metabolic anomalies.

Concentrations of vanadium in mushrooms are often below $1 \mathrm{mg} / \mathrm{kg}$ dry weight (Meisch et al. 1978 \& Randa et al. 2005). Amanita muscaria, A. regalis and A. velatipes are known to accumulate vanadium in high concentrations Koch et al. 1987. Concentrations are known to range from the tens to the lower hundreds of $\mathrm{mg} / \mathrm{kg}$ DW (Koch et al. 1987 \& Meisch et al. 1978).

Vanadium compounds have been demonstrated to mimic the action of insulin in isolated cell systems, animal models and diabetic patients. This has brought the use of $\mathrm{V}$ compounds as potential sources of diabetes therapy into focus (Shechter 1990, \& Shamberger 1996). Furthermore, Vanadium compounds positively affected glucose metabolism in streptozotocin-diabetic rats (Reul BA et al. 1999) Again, at the genetic level, it was demonstrated that Vanadate treatment of diabetic rats reversed the impaired expression of genes involved in hepatic glucose metabolism (Brichard SM et al. 1993) The intake of vanadium from normal food is estimated to be of the order of $10-20 \mu \mathrm{g} /$ day. This daily intake is at least three orders of magnitude below the lowest doses reported to cause adverse effects (EFSA). While the EFSA indicates no upper tolerable limits for vanadium, the US Food and Nutrition Board (FNB) 
recommend $1.8 \mathrm{mg} /$ day for both males and females.

Costa-Silva F. et al. 2011, reported on the Selenium contents of Portuguese commercial and wild edible mushrooms. Their report indicated that high selenium contents were found in the wild species Boletus aestivalis (48.5 mg/kg dry weight, DW), Boletus pinophilus (19.9 mg/kg DW), Boletus edulis (14.9 mg/kg DW), Boletus aereus $(12.3 \mathrm{mg} / \mathrm{kg} \mathrm{DW})$, Boletus fragans and Boletus spretus $(\approx 2 \mathrm{mg} / \mathrm{kg}$ DW). Considerable selenium content was found in Marasmius oreades (1.5 mg/kg DW), Agaricus bisporus"'Portobello" (1.25 mg/kg DW), A. bisporus (1.0 mg/kg DW) and Russula cyanoxantha $(0.72 \mathrm{mg} / \mathrm{kg}$ DW). Pleurotus ostreatus, Cantharellus cibarius, and a few others were found to have very small amounts of selenium.

Selenium have been shown to reduce the risk of developing dysglycemia- a broad term that refers to any abnormalities in blood glucose levels leading to disease (Akbaraly TN et al. 2010). It is also thought to work by exerting insulin-like actions in vitro (Becker DJ et al. 1996). It was concluded by researchers that selenate induces a sustained improvement of glucose homeostasis in streptozotocin-diabetic rats by an insulin-like action, which involves partial correction of altered pretranslational regulatory mechanisms in liver metabolism (Becker DJ et al. 1996). Some studies have however cast doubt on the benefits of selenium in aiding sugar metabolism (Stranges S. et al. 2007) An Upper Limit of $300 \mu \mathrm{g}$ Se/day was derived for adults by the EFSA. This value covers selenium intake from all sources of food, including supplements.

With the increasing incidence of type 2 diabetes in Ghana (Danquah et al. 2012, \& Amoah AG. et al. 2002), and the search for alternative treatments, it is important to determine if it is possible for dietary interventions made of mushroom complexes or nutrient- enriched mushrooms to be promoted as part of a healthy diet that supports glucose metabolism. This work was therefore carried out to determine if these mushrooms, that are increasingly used by Ghanaian mushroom lovers may contribute to reduction of the incidence of type 2 diabetes and also its management.

\section{Materials and Methods}

\section{Sampling}

The samples examined in this research included 31 fungi samples collected from various locations. Pleorotus ostreatus was obtained from a small scale farmer located at Aburi, near Accra. Termitomyces clypeatus (edible mushroom) was purchased from the open market at Makola, located in the central business district in the Ghanaian capital Accra. Agaricus bisporus was obtained from the Accra Mall, the largest shopping centre in the city while Ganoderma lucidum was collected from the wild near the banks of the Volta River.

The mushroom species were identified based on microscopic and morphological characteristics of the mushrooms according to methods set out by Pegler (1977) Phillips (1981Courtecuisse and Duhom (1995), Laessoe (1998), and Ryvarden and Johansen (1980).

\section{Sample Preparation}

Oyster mushroom, wild Ganoderma mushroom, edible mushroom and button mushroom were freeze - dried for 3 days to remove all moisture from the samples. The following digestion protocol was used for the analysis of heavy metals in mushroom with Atomic Absorption Spectrometer (AAS). The different species of mushrooms; Pleurotus ostreatus (oyster mushroom), Agaricus bisporus (button mushroom), Ganoderma lucidum (wild Ganoderma), Termitomyces clypeatus (common edible mushroom), were bought from each of the identified markets above. They were individually cleaned, cut into pieces and placed in a labeled special glass container and then freeze dried under high pressure. The dried mushroom sample was then thoroughly blended into powdered form. $0.50 \mathrm{~g}$ of the milled samples was weighed into Teflon beakers. $6 \mathrm{ml}$ of concentrated $\mathrm{HNO}_{3}(65 \%)$ and $1 \mathrm{ml}$ of $\mathrm{H}_{2} \mathrm{O}_{2}(30 \%)$ were added to the samples, covered tightly in Teflon bombs and loaded onto the rotor using the wrench or torque in the fume chamber. The rotor with the Teflon bombs was placed in the ETHOS 900 Microwave Digester and digested using the Microwave Programme (Report Code: 183). The complete assembly was microwaved for 25 
minutes using Milestone Microwave Lab Station ETHOS 900, MLS-1200. After digestion the Teflon bombs mounted on the microwave carousel were cooled in a water bath to reduce internal pressure and allow volatilized material to re-stabilize. The digestate was made up to $20 \mathrm{ml}$ with double distilled water and assayed for the presence of chromium (Cr), vanadium (V), and Selenium (Se) using VARIAN AA240 FS-Atomic Absorption Spectrometer in an acetylene air flame. The reference standards for each of the elements of interest, blanks and duplicates of the samples were digested under the same condition as the samples. These served as internal positive controls. Reference standard were obtained from FLUKA ANALYTICAL, Sigma-Aldrich Chemie GmbH, of Switzerland.

\section{Statistical tool and analysis employed}

ANOVA was the statistical tool used to estimate the statistical significances at $95 \%$ Confidence Interval.

\section{Results}

The concentration of these metals - Chromium(Cr), Vanadium(V), and Selenium(Se), as determined by Atomic Absorption Spectrophotometry (AAS) was found to be $0.6 \mathrm{mg} / \mathrm{kg}, 0.4 \mathrm{mg} / \mathrm{kg}$, and $334.48 \mathrm{mg} / \mathrm{kg}$ respectively in button mushroom, $1.3 \mathrm{mg} / \mathrm{kg}, 0.4 \mathrm{mg} / \mathrm{kg}$, and $375.78 \mathrm{mg} / \mathrm{kg}$ respectively in edible mushroom, $0.2 \mathrm{mg} / \mathrm{kg}, 0.4 \mathrm{mg} / \mathrm{kg}$, and $466.12 \mathrm{mg} / \mathrm{kg}$ respectively in oyster mushroom, and $0.96 \mathrm{mg} / \mathrm{kg}, 0.4 \mathrm{mg} / \mathrm{kg}$, and $420.06 \mathrm{mg} / \mathrm{kg}$ respectively in Ganoderma lucidum. The highest concentration of these metals were $\mathrm{Cr}(1.3 \mathrm{mg} / \mathrm{kg})$ in Termitomyces clypeatus; $\mathrm{V}(0.4$ $\mathrm{mg} / \mathrm{kg}$ ) same for all of them; and Se $(466.12 \mathrm{mg} / \mathrm{kg})$ in Pleorotus ostreatus. The results are displayed below in table 1.

Table 1 Showing mean concentration $(\mathrm{mg} / \mathrm{kg})$ of elements in fresh mushrooms

\begin{tabular}{lccc}
\hline Specie name & $\mathbf{C r}$ & $\mathbf{V}^{\dagger}$ & $\mathbf{S e}^{\boldsymbol{\alpha}}$ \\
\hline Agaricus bisporus & 0.6 & 0.4 & 334.48 \\
Termitomyces & 1.3 & 0.4 & 375.78 \\
$\begin{array}{l}\text { clypeatus } \\
\text { Pleurotus ostreaus }\end{array}$ & 0.2 & 0.4 & 466.12 \\
Ganoderma lucidum & 0.96 & 0.4 & 420.06 \\
\hline
\end{tabular}

+ Statistically significant difference in the $\mathrm{Cr}$ content at $5 \%$ significant level $\mathrm{p}=0.001$
$\dagger$ No statistically significant difference in the V content at $5 \%$ significant level $\mathrm{p}=0.00$
$\alpha$ Statistically significant difference in the Se content at $5 \%$ significant level $\mathrm{p}=0.001$

\section{Discussion}

The order of concentration for $\mathrm{Cr}$ in the mushrooms was found to be in the order Termitomyces clypeatus $(1.3 \mathrm{mg} / \mathrm{kg})>$ Ganoderma lucidum $(0.96 \mathrm{mg} / \mathrm{kg})>$ Agaricus bisporus $(0.6$ $\mathrm{mg} / \mathrm{kg}$ ) > Pleorotus ostreatus $(0.2 \mathrm{mg} / \mathrm{kg}$ ). Analysis of Variance (ANOVA) performed at $95 \%$ Confidence Interval revealed that there is statistically significant difference between the chromium content in the four biomass (button mushroom, edible mushroom, oyster mushroom and wild Ganoderma) analyzed, since the $\mathrm{p}<0.05$.

For $\mathrm{V}$, the order was found to be $0.4 \mathrm{mg} / \mathrm{kg}$ for all. In the case of Se, it was Pleorotus ostreatus (466.12 mg / $\mathrm{kg})>$ Ganoderma lucidum (420.06 mg / $/ \mathrm{kg})>$ Termitomyces clypeatus $(375.78 \mathrm{mg} / \mathrm{kg}$ ) > Agaricus bisporus $(334.48 \mathrm{mg} / \mathrm{kg}$ ). Analysis of Variance (ANOVA) performed at $95 \%$ Confidence Interval revealed that there is statistically significant difference between the Selenium content in the four biomass (button mushroom, edible mushroom, oyster mushroom and wild Ganoderma) analyzed, since the $\mathrm{p}<0.05$.

The Office of Dietary Supplements (ODS), part of the National Institutes of Health (NIH), suggests adequate levels of chromium of about 35 micrograms a day for men up to age 50, and 20 micrograms daily for men older than 50 . The recommendation is 25 micrograms for women up to age 50, and 20 micrograms for women older than 50 (http://ods.od.nih.gov/factsheets/Chromium- 
HealthProfessional/). This implies that Termitomyces clypeatus, which contains $1.3 \mathrm{mg} / \mathrm{kg}(1.3$ $\mu \mathrm{g} / \mathrm{g}$ ) Cr can supply about four times the recommendation for men less than 50 years who consume about a hundred grams of Termitomyces clypeatus.

On issues of toxicity, Mertz (1975) reports that few cases of systemic intoxication by $\mathrm{Cr}$ ingestion in man or animals have been reported. The $\mathrm{LD}_{50}$ was 18 and $60 \mathrm{mg}$ of $\mathrm{Cr}$ per kilogram body weight respectively for chromium as chromalum $\left[\mathrm{KCr}\left(\mathrm{SO}_{4}\right)_{2} \cdot 2 \mathrm{H}_{2} \mathrm{O}\right]$ and chromium (III) nicotinic acid complex with high GTF activity in rats injected intravenously (Mertz, 1975, Mertz \& Roginski, 1975). As few serious adverse effects have been linked to high intakes of chromium, the Institute of Medicine has not established a Tolerable Upper Intake Level (UL) for this mineral (Stoecker BJ 2001, FNB 2001). The amount of $\mathrm{Cr}$ found in these mushrooms is generally comparable to those found in other similar research (Dobrinas S. et al. 2013). With the evidence here adduced, it may be safe to say that Termitomyces clypeatus, which is very common in Ghana may be a rich source of $\mathrm{Cr}$ and may be included in diets of type 2 diabetics to improve the management of the disease. It may also be incorporated into mushroom nutrient complexes in an attempt to minimize the incidence of diabetes.

It's been indicated earlier that the EFSA indicates no upper tolerable limits for vanadium. However the US FNB recommends $1.8 \mathrm{mg}$ /day for both males and females. The amount of Vanadium in all the mushrooms tested was $0.4 \mathrm{mg} / \mathrm{kg}$. Each of these mushrooms may therefore act as vanadium supplements without any adverse effects on man. A median value $(n=77)$ for $V$ in several mushrooms was given as $0.25 \mathrm{mg} / \mathrm{kg}$ dry matter (Svoboda et al. 2007). Byrne \& Kosta (1978) reported vanadium concentrations in food ranging from 1-30 micrograms $/ \mathrm{kg}$ fresh weight. The highest concentration of $\mathrm{V}$ was recorded in parsley, dry mushrooms and oysters. At $0.4 \mathrm{mg} / \mathrm{kg}$, it may be said that the amount of $\mathrm{V}$ in these mushrooms tested are rather low but safe for consumption.

Unlike Cr, vanadium is known to act by mimicking the action of insulin (Shechter 1990 \& Shamberger 1996) They therefore offer a different mode of influencing glucose metabolism from $\mathrm{Cr}$, which functions through its biologically active form, the glucose-tolerance factor (GTF) to reduce glucose intolerance (Schroeder HA. 1966, Jeejeeboy KN et al. 1977 \& Freund H et al. 1979). Consequently, a mushroom complex combination of these mushrooms may offer alternate routes to influence positively the general outlook for diabetic prevention and treatment.

The role of selenium appears to be that of improving glucose homeostasis (Becker DJ et al. 1996), thus avoiding degeneration of dysglycemia into pathological conditions like type 2 diabetes. The Dietary Reference Intake for Selenium in the USA in 2000 was $55 \mu \mathrm{g}$ /day for adult men and women, as determined by the Office of Dietary Supplements (ODS) of the NIH (http://ods.od.nih.gov/factsheets/Selenium-HealthProfessional/). The safe upper limit for Se is given as $400 \mu \mathrm{g} / \mathrm{d}$ by the ODS. From the results, the amount of Se in all the mushrooms range from $466.12 \mathrm{mg} / \mathrm{kg}(46.6 \mu \mathrm{g} / \mathrm{g})$ in Pleorotus ostreatus to $334.48 \mathrm{mg} / \mathrm{kg}(33.4 \mu \mathrm{g} / \mathrm{g})$ in Agaricus bisporus. Values obtained in similar research work ranged from $0.048 \mathrm{mg} / 100 \mathrm{~g}$ dry weight in Pleurotus florida to $0.19 \mathrm{mg} / 100 \mathrm{~g}$ dry weight in Lentinus cladopus (Mallikarjuna S.E. et al. 2013). The values obtained in this work show that these mushrooms may be a good and safe source of dietary selenium.

\section{Conclusion}

It may be concluded that the mushrooms here examined may be considered safe as sources of trace minerals reputed to be of some value in the metabolism of glucose and hence beneficial in controlling the incidence and management of type 2 diabetes and its effects. A regular and judicious consumption of these mushrooms may be promoted as a positive addition to a healthy diet in Ghana and most West African countries where these mushrooms abound.

\section{References}

Akbaraly TN, Arnaud J, Rayman MP, Hininger- Favier I, Roussel AM, Berr C, Fontbonne A. 2010 
- Plasma selenium and risk of dysglycemia in an elderly French population: Results from the prospective epidemiology of Vascular Ageing Study. Nutr Metab Lond. 2010 Mar $18 ; 71: 21$.

Amoah AG, Owusu SK, Adjei S. 2002 - Diabetes in Ghana: a community based prevalence study in Greater Accra. Diabetes Res Clin Pract. 2002 Jun; 563:197-205.

Anderson RA, Cheng N, Bryden NA, Polansky MM, Cheng N, Chi J, Feng J. 1997 - Elevated intakes of supplemental chromium improve glucose and insulin variables in individuals with type 2 diabetes. Diabetes. 1997 Nov; 4611:1786-91.

Becker DJ, Reul B, Ozcelikay AT, Buchet JP, Henquin JC, Brichard SM. 1996 - Oral selenate improves glucose homeostasis and partly reverses abnormal expression of liver glycolytic and gluconeogenic enzymes in diabetic rats. Diabetologia. 1996 Jan; 391:3-11.

Brichard SM, Desbuquois B, Girard J. 1993 - Vanadate treatment of diabetic rats reverses the impaired expression of genes involved in hepatic glucose metabolism: effects on glycolytic and gluconeogenic enzymes, and on glucose transporter GLUT2. Mol Cell Endocrinol. 1993 Feb; 911- 2:91-7.

Byrne AR and Kosta L. 1978 - Vanadium in foods and in human body fluids and tissues, Sci. Total Environ. 10:17- 30 Chemistry, 86, 547-552.

Costa-Silva F, Marques G, Matos C. C, Barros Ana I.R.N.A, Nunes FN. 2011 - Selenium contents of Portuguese commercial and wild edible mushrooms. Food Chemistry 126: 9196

Courtecuisse R. and Duhom B. 1995 - Mushrooms and Toadstools of Britain and Europe. Collins Field Guide. Harper Collins Publishers, London.

Danquah I, Bedu- Addo G, Terpe KJ, Micah F, Amoako YA, Awuku YA, Dietz E, van der Giet M, Spranger J and Mockenhaupt FP. 2012 - Diabetes mellitus type 2 in urban Ghana: characteristics and associated factors. BMC Public Health, 2012, 12:210

Davidson IWF, Blackwell WL. 1968 - Changes in carbohydrate metabolism of squirrel monkeys with chromium dietary supplementation. Proc Soc Exp Biol Med 1968; 127:66-72. DOI : $10.1080 / 02652030701458519$.

Demirbaş A 2001. Concentrations of 21 metals in 18 species of mushrooms growing in the East Black Sea region. Food Chemistry Volume 75, Issue 4, December 2001, Pages 453-457. http://dx.doi.org/10.1016/S0308-8146(01)00236-9

Dobrinas S, Soceanu A, Stanciu G, Popescu V, and Arnold GL 2013 - Trace element levels of three mushroom species. Ovidius University Annals of Chemistry 24 (1), 39- 42.

Freund H, Atamian S, Fischer JE. 1979 - Chromium deficiency during total parenteral nutrition. JAMA 1979; 241: 496-498

Ghaly IS, Ahmed ES, Booles HF, Farag IM and Nada SA. 2011 - Evaluation of Antihyperglycemic Action of Oyster Mushroom Pleurotus ostreatus and Its Effect on DNA Damage, Chromosome Aberrations and Sperm Abnormalities in Streptozotocin- Induced Diabetic Rats, Global Veterinaria 2011;76: 532-544.

http://ods.od.nih.gov/factsheets/Chromium-HealthProfessional/ (accessed 10 February 2014).

http://ods.od.nih.gov/factsheets/Selenium-HealthProfessional/ (accessed 10 February 2014).

Institute of Medicine, Food and Nutrition Board 2001 - Dietary Reference Intakes for Vitamin A, Vitamin K, Arsenic, Boron, Chromium, Copper, Iodine, Iron, Manganese, Molybdenum, Nickel, Silicon, Vanadium, and Zinc. National Academy Press, Washington, DC, 2001.

Isildak, Ö, Türkekul I, Elmastas M, \& Tüzen, M. 2004 - Analysis of heavy metals in some wildgrown edible mushrooms from the middle Black Sea region, Turkey. Food Chemistry, 86, $547-552$

Jeejeeboy KN, Chu RC, Marliss EB, Greenberg GR, Bruce-Robertson A. 1977 - Chromium deficiency, glucose intolerance, and neuropathy reversed by chromium supplementation, in a patient receiving long- term total parenteral nutrition. Am J Chin Nutr 1977; 30: 531-8.

$\mathrm{Kalac}^{`}$ P. 2010 - Trace element contents in European species of wild growing edible mushrooms: A review for the period 2000-2009. Food Chemistry 122: 2-15 
Koch E, Kneifel H, and Bayer E 1987 - Occurrence of Amavadin in Mushrooms of the Genus Amanita, Z. Naturforsch. 42c (1987) 873-878.

Konuk M, Ahmet A, Dursun Y. 2007 - Minor element and heavy metal contents of wild growing and edible mushrooms from western Black Sea region of Turkey. Fresenius Environmental Bulletin, Volume 16 - No 11a. 2007

Laessoe T, 1998 Mushrooms - The Visual Guide to over 500 species of Mushrooms from around the world. Darling Kindersley Ltd, London.

Meisch H U, Benzschawel H. 1978 - The role of vanadium in green plants. III. Influence on cell division of Chlorella. Arch. Microbiol. 116, 91-95

Mertz W, Roginski EE. 1975 - Some biological properties of chromium Cr- Nicotinic Acid NA Complexes, Fed Proc 34:922Abstr.

Mertz W. 1975 - Effects and Metabolism of Glucose Tolerance Factor; Nutrition Reviews, Volume 33, Issue 5, pages 129-135, May 1975; DOI: 10.1111/j.1753-4887.1975.tb07105.x

Pegler DN 1977 - A preliminary Agaric. Flora of East Africa. Kew Bulletin Additional Series 6:1615.

Phillips R. 1981 - Mushrooms and Other Fungi of Great Britain and Europe. Pan Books Ltd. London.

Řanda Z, Soukal L, Mizera J. 2005 - Possibilities of the short-term thermal and epithermal neutron activation for analysis of macromycetes (mushrooms). Journal of Radioanalytical and Nuclear Chemistry, March 2005, Volume 264, Issue 1, pp 67-76

Reul BA, Amin SS, Buchet JP, Ongemba LN, Crans DC, Brichard SM 1999 - Effects of vanadium complexes with organic ligands on glucose metabolism: a comparison study in diabetic rats. Br J Pharmacol. 1999 Jan; 1262:467-77.

Ryvarden, L and Johansen I. 1980 - A preliminary polypore flora of East Africa. Oslo.

S.E. Mallikarjuna, A.Ranjini, Devendra J. Haware, M.R. Vijayalakshmi, M.N. Shashirekha, and S. Rajarathnam. 2013 - Mineral Composition of Four Edible Mushrooms. Journal of Chemistry, Volume 2013, Article ID 805284, 5 pages. http://dx.doi.org/10.1155/2013/805284

Sang Chul Jeong, Yong Tae Jeong, Byung Keun Yang, Rezuanul Islam, Sundar Rao Koyyalamudi, Gerald Pang, Kai Yip Cho, Chi Hyun Song 2010 - White button mushroom Agaricus bisporus lowers blood glucose and cholesterol levels in diabetic and hypercholesterolemic rats. Nutrition Research 302010 49-56.

Schroeder HA 1966 - Chromium deficiency in rats: a syndrome simulating diabetes mellitus with retarded growth. J Nutr 1966; 88:439- 45

Shamberger RJ 1996 - The insulin- like effects of vanadium. J Adv Med 9: 121-131.

Shechter Y 1990 - Insulin- mimetic effects of vanadate. Possible implications for future treatment of diabetes. Diabetes 39: 1-5.

Stoecker BJ 2001 - Chromium. In: Present Knowledge in Nutrition, 8th Edition edited by Bowman B, Russell R. ILSI Press, Washington, DC, 2001, pp. 366- 372.

Stranges S, Marshall JR, Natarajan R, Donahue RP, Trevisan M, Combs GF, Cappuccio FP, Ceriello A, Reid ME. 2007 - Effects of long-term selenium supplementation on the incidence of type 2 diabetes: a randomized trial. Ann Intern Med. 2007 Aug 21;1474:21723. Epub 2007 Jul 9.

Svoboda L, Ceske B, Chrastny V. 2007 - Contents of eight trace elements in edible mushrooms from a rural area. Food Additives and Contaminants, 25, 01, 51- 58

Wolliscroft J, Barbosa J. 1977 - Analysis of chromium induced carbohydrate intolerance in the rat. J Nutr 1977; 107: 1702-1706.

Yang BK, Kim DH, Jeong SC, Das S, Choi YS, Shin JS, Lee SC, Song CH 2002 - Hypoglycemic effect of a Lentinus clypeatus exopolymer produced from a submerged mycelial culture. Biosci. Biotechnol. Biochem. 2002, 66, 937-942.

Zhang HN, Lin ZB. 2004 - Hypoglycemic effect of Ganoderma lucidum polysaccharides. Acta Pharmacologica Sinica. 25:191- 195. 2004. 